\title{
MANAJEMEN KAWASAN WISATA LEMBAH HARAU KABUPATEN LIMA PULUH KOTA
}

\section{MANAGEMENT OF LEMBAH HARAU WISATA AREA KABUPATEN LIMA PULUH KOTA}

\author{
Deki Yusman $^{1)^{*}}$, Nursyirwan Effendi ${ }^{2)}$, Ifdal $^{3)}$ \\ 1,2,3) Pembangunan Wilayah dan Pedesaan Program Pascasarjana Unand, \\ yusmandeki@gmail.com
}

\begin{abstract}
ABSTRAK: Tujuan penelitian ini adalah untuk melihat bagaimana pengelolaan kawasan wisata Lembah Harau dan bagaimana peranan pemangku kepentingan (stakeholder) dalam mengelolanya. Metoda yang dipakai untuk mendapatkan hasil penelitian ini dilakukan dengan metode dekriptif kualitatif, dengan mendeskripsikan kondisi yang ditemukan dilapangan serta membandingkannya dengan literatur yang ada. Hasil penelitian ini mengemukakan bahwa manajemen dalam pengelolaan kawasan wisata Lembah Harau saat ini belum optimal karena fungsi-fungsi manajemen dalam pengelolaannya belum terlaksana dengan baik. Dalam pengelolaan Kawasan wisata Lembah Harau peran swasta dalam saat ini sangat menonjol, hal ini dapat terlihat dari semakin banyaknya atraksi, wahana, penginapan dan sarana penunjang wisata lainnya yang berkembang di kawasan wisata Lembah Harau, namun hal ini tidak diringi dengan pengawasan yang dilakukan dinas terkait
\end{abstract}

Kata Kunci: Manajemen, Pengelolaan, Pariwisata, Peran, Stakeholder

ABSTRACT: The purpose of this research is to see how the management of the Harau Valley tourist area and how the roles of stakeholders in managing it. The method used to obtain the results of this study was carried out with a qualitative descriptive method, by describing the conditions found in the field and comparing them with existing literature. The results of this study suggest that the management in the management of the Harau Valley tourism area is currently not optimal because the management functions in its management have not been implemented properly. In the management of the Harau Valley tourist area, the role of the private sector is currently very prominent, this can be seen from the increasing number of attractions, rides, lodging and other tourism support facilities that are developing in the tourist area of the Harau Valley, but this is not accompanied by supervision carried out by related agencies.

Keywords: Management, Management, Tourism, Role, Stakeholders

\section{A. PENDAHULUAN}

Indonesia merupakan negara kepulauan yang memiliki sumberdaya alam laut dan darat yang melimpah. Sumberdaya alam tersebut digunakan untuk memenuhi kebutuhan hidup manusia. Pemilihan sektor pariwisata sebagai salah satu sumber devisa negara karena dianggap sektor ini memiliki hambatan yang relatif kecil dibandingan sektor lainnya.

Pariwisata mempunyai peran yang sangat penting dalam pembangunan Indonesia khususnya sebagai penghasil devisa negara disamping sektor migas. Sebagai sumber devisa, pariwisata menyimpan potensi yang sangat besar. Selain itu, industri pariwisata bermodal besar juga pernah menjadi idola bagi pertumbuhan ekonomi negara ini, sebut saja industri pariwisata di Pulau Bali, sebelum akhirnya jatuh akibat tragedi bom Bali. Terlepas dari pengalaman tragedi bom Bali sejatinya pariwisata merupakan alternatif industri yang strategis untuk mendorong pembangunan wilayah mengingat industri pariwisata termasuk industri yang minim limbah 
(Sunaryo, 2013). Selain itu, pariwisata adalah industri yang berkelanjutan atau tidak lekang oleh waktu, tentunya ketika diperbandingkan dengan industri pertambangan dan manufaktur yang semakin lama semakin melemah. Pariwisata menjadi industri yang memiliki daya jual yang tidak akan pernah habis.

Pariwisata menjadi industri yang memiliki daya jual yang tidak akan pernah habis. Pariwisata merupakan salah satu sub sektor ekonomi yang cukup mendapat Pariwisata merupakan salah satu sub sektor ekonomi yang dinilai mampu mensejahterakan kehidupan masyarakat. Pembangunan pariwisata tidak terlepas dari pengelolaan sumber daya alam, sumber daya manusia, dan sumber daya penunjang lainnya. Keterlibatan dan peran serta stakeholders dan sub sektor ekonomi lainnya dapat mendukung keberhasilan suatu pembangunan pariwisata. pariwisata, meliputi alam dan budaya serta pengembangan ekowisata disalah satu Wilayah Pengembangan Pariwisata di Kabupaten 50 Kota.

Salah satu upaya untuk mewujudkan agar sektor objek wisata mampu meningkatkan perekonomian, sosial dan lingkungan adalah dengan melakukan pengembangan dan pengelolaan yang baik terhadap objek wisata tersebut. Banyak macam potensi wisata yang dikembangkan di berbagai Negara, seperti wisata budaya, wisata sejarah, wisata alam dan lain sebagainya, begitu juga di Indonesia. Seperti yang telah disampaikan sebelumnya bahwa pengembangan objek wisata dapat dijadikan sebagai aktivitas perekonomian yang dengan sangat cepat dapat menghasilkan devisa Negara (quick yielding).

Berdasarkan hal tersebut maka dapat dikatakan bahwa pengelolaan dan pengembangan objek wisata merupakan jembatan untuk mengembangkan sektor usaha lainnya, seperti, hotel, industri kerajinan daerah, kuliner, perjalanan wisata dan akhirnya dapat membuka lapangan pengerjaan bagi masyarakat sekitar sehingga dapat meningkatkan perekonomian masyarakat.

Kabupaten Lima Puluh Kota merupakan bagian wilayah di Propinsi Sumatera Barat yang dilalui kawasan Bukit Barisan dan memiliki keragaman topografi potensi alam seperti sungai, air terjun, ngarai, hutan dengan berbagai jenis flora dan fauna dan sebagainya. Pemerintah Kabupaten Lima Puluh Kota sudah melakukan pengembangan terhadap potensi pariwisata yang dimilikinya, baik itu wisata alam, wisata budaya, dan wisata sejarah. Pengembangan objek wisata yang berada di Kabupaten Lima Puluh Kota memiliki keuntungan yang sangat besar baik bagi pemerintah maupun masyarakat, sebagai penambah devisa dan penggerak perekonomian serta promosi hasilhasil industri pariwisata masyarakat. Salah satu daerah tujuan wisata dan juga merupakan kawasan wisata unggulan di Kabupaten Lima Puluh Kota adalah Lembah Harau yang berjarak kurang lebih 176 kilo meter atau empat jam perjalanan dari ibukota Provinsi Sumatera.

Objek Wisata Lembah Harau sebagaimana yang tertuang pada Peraturan Daerah Nomor 7 tahun 2012 tentang Rencana Tata Ruang Wilayah Kabupaten Lima Puluh Kota telah dinyatakan sebagai salah satu dari tiga objek wisata unggulan di Kabupaten Lima Puluh Kota. Selain itu secara faktual Lembah Harau memiliki kekayaan keindahan tebing-tebing dan air terjun yang dipadukan dengan suasana alam yang masih sangat alami yang mengundang wisatawan lokal dan luar negeri dari tahun ke tahun selalu meningkat, dimana Dinas Pariwisata Kabupaten Lima Puluh Kota mencatat bahwa pada tahun 2012 lebih dari 150 ribu wisatawan domestik dan lebih dari 3 ribu wisatawan mancanegara berkunjung ke Lembah Harau.

Pengelolaan dan perkembangan objek wisata Lembah Harau serta faktor penunjangnya memiliki makna penting dalam menentukan keberhasilan pembangunan wilayah, karena dengan pengelolaan yang baik maka objek wisata dapat berkembang dengan baik dan begitu juga dengan faktor penunjangnya yang pada akhirnya akan memberikan kesejahteraan secara optimal dan adil kepada masyarakat setempat. Dengan demikian apabila kegiatan objek wisata tersebut memiliki dampak positif kepada masyarakat setempat, maka akan menimbulkan rasa peduli dan sikap selalu menjaga objek tersebut dari berbagai kerusakan. Hal ini sejalan dengan pendapat.

Objek wisata Lembah Harau memiliki potensi untuk terus dikembangkan, karena karena lokasinya yang strategis, objek wisata yang menarik, masyarakat yang ramah dan terbuka, memiliki atraksi alam dan buatan, kondisi jalan menuju objek wisata tergolong baik, serta udaranya yang sejuk. Selain potensi yang ada, objek wisata ini juga memiliki berbagai kelemahan, diantaranya akses masuk dan keluar menuju objek wisata hanya terdapat satu jalur, jalan yang menghubungkan 
objek wisata yang satu dengan yang lainnya tergolong kecil dan sempit dan juga jarak antara objek wisata yang satu dengan yang lainnya terlalu jauh, sehingga membuat pengunjung terkadang hanya fokus pada satu objek wisata saja. Kelemahan yang ditemukan juga pada objek wisata ini adanya beberapa tempat tersembunyi dikawasan wisata tersebut, sehingga mengundang terjadinya hal-hal yang tidak diinginkan. Hal ini merupakan tantangan bagi Pemerintah Lima Puluh Kota untuk lebih memperhatikan pengembangan objek wisata ini, agar menjadi objek wisata yang diminati banyak pengunjung sehingga dapat meningkatkan Pendapatan Asli Daerah (PAD).

Berdasarkan hasil data yang ditemukan dilapangan setiap tahunnya terdapat peningkatan aktivitas yang dilakukan masyarakat serta meningkatnya jumlah wisatawan yang berkunjung pada objek wisata Lembah Harau. Dengan meningkatnya jumlah wisatawan yang berkunjung mengundang pihak swasta untuk berinvestasi pada kawasan objek wisata Lembah Harau. Hal ini dapat dilihat dari semakin tidak terkendalinya pembangunan hotel/ penginapan dan resort pada kawasan wisata Lembah Harau, serta munculnya restoran asing pada kawasan wisata Lembah Harau yang menyebabkan hilangnya kuliner khas Kabupaten Lima Puluh.

Dari latar belakang tersebut, maka rumusan masalah dalam penelitian ini adalah:

1. Bagaimana pengelolaan Kawasan Wisata Lembah Harau selama ini ?

2. Apa saja peran pemangku kepentingan (stakeholder) dalam pengelolaan kawasan Wisata Lembah Harau?

\section{B. METODE PENELITIAN}

\section{Jenis Penelitian}

Penelitian ini bersifat deskriptif kualitatif. Denzin dan Lincoln dalam Moleong (2012) menyatakan bahwa penelitian kualitatif adalah penelitian yang dilakukan dengan memanfaatkan lingkungan alam yang bertujuan untuk menjelaskan terjadinya suatu fenomena atau keadaan, dan dilaksanakan dengan melibatkan berbagai metode yang ada. Bogdan dan Taylor dalam Moleong (2012) juga mendefinisikan metodologi kualitatif sebagai prosedur penelitian yang menghasilkan data deskriptif dari ekspresi tertulis atau lisan serta perilaku yang dapat diamati dari orang yang kita teliti. Sejalan dengan definisi tersebut, Kirk dan Miller dalam Moleong (2012) mendefinisikan bahwa penelitian kualitatif merupakan metode penelitian khusus dalam ilmu sosial, yang pada dasarnya bertumpu pada pengamatan manusia dalam bidang dan aspeknya.

Dengan menggunakan metode penelitian deskriptif ini diharapkan dapat menggambarkan secara terperinci dan lebih detail mengenai pengelolaan objek wisata Lembah Harau. Dengan rancangan penelitian secara deskriptif kualitatif, penulis akan mengumpulkan data melalui pendekatan objek penelitian yang akan menggali informasi yang dibutuhkan dalam penelitian ini berdasarkan persepsi penulis dan informasi dari informan yang nantinya akan berkembang pada saat interaksi yang terjadi saat pelaksanaan wawancara.

Populasi merupakan semua objek penelitian yang memiliki hubungan dengan permasalahan penelitian yang ditemukan terhadap suatu kasus seseorang atau individu serta gejala yang terdapat pada daerah penelitian. Populasi pada penelitian ini meliputi seluruh gejala individu, dan masalah yang berkaitan dengan kegiatan pengelolaan wisata di Kawasan wisata Lembah Harau yakni Instansi pemerintah, Perangkat nagari, dan pihak swasta.

\section{Populasi dan Sampel (Informan) Penelitian}

Sampel adalah unit dalam ruang lingkup yang akan diteliti merujuk kepada syarat dan kebutuhan penelitian. Sampel dalam penelitian ini adalah personal atau unit yang mengetahui, beraktivitas dan terlibat dalam segala sesuatu yang berhubungan dengan Kawasan wisata Lembah Harau Kecamatan Harau Kabupaten Lima Puluh Kota. Dalam penelitian ini dibutuhkan informasi mengenai Kawasan Wisata Lembah Harau melalui sampel, dengan begitu sampel menjadi informan yang bisa dijadikan sumber data untuk menjawab tujuan penelitian. 
Informan merupakan orang yang dapat memberikan informasi mengenai situasi dan kondisi dari objek penelitian. Informan yang dipilih harus memiliki pengetahuan atau informasi yang lebih detail terhadap objek yang akan diteliti. Selain itu seorang informan yang dipilih juga harus orang yang terlibat langsung dalam kejadian atau masalah penelitian yang kita lakukan serta memiliki kompetensi dalam bidang yang diteliti tersebut (Sugiyono, 2009).

Dalam penelitian ini penulis memilih informan secara purposive kepada unsur masyarakat, agar informasi yang didapat dari objek penelitian sesuai dapat menjawab tujuan penelitian. Penulis memilih atau menetapkan informan berdasarkan pertimbangan bahwa informan tersebut memahami dan mengetahui tentang objek penelitian yang dilakukan.

Berdasarkan hal tersebut, untuk menjawab pertanyaan pada penelitian ini maka penulis memilih informan berikut untuk menjadi sumber data :

Tabel 1. Informan Penelitian

\begin{tabular}{llc}
\hline \multicolumn{1}{c}{ INFORMAN } & JUMLAH \\
\hline 1. BAPPELITBANG Kab. Lima Puluh Kota & 1 \\
2. Dinas Pariwisata Kab. Lima Puluh Kota & \\
3. Dinas PUPR Kab Lima Puluh Kota & \\
4. BKSDA Prov Sumatera Barat & 1 \\
5. Camat Kecamatan Harau & 1 \\
6. Perangkat Nagari & 3 \\
& $\begin{array}{l}\text { 1. Wali Nagari } \\
\text { 2. Perwakilan Bamus }\end{array}$ & 3 \\
3. Wali Jorong & 3 \\
7. Unsur Masyarakat Tiap Jorong & 3 \\
& $\begin{array}{l}\text { a. Jorong Lubuak Limpato Nagari Tarantang } \\
\text { b. Jorong Tarantang Nagari Tarantang } \\
\text { c. Jorong Tarok Nagari Harau }\end{array}$ \\
8. Unsur swasta yang terlibat dalam aktifitas (pedagang, & 3 \\
pemilik homestay, dan pekerjaan lainnya) & 9 \\
9. Pengunjung (wisatawan) & 3 \\
\hline
\end{tabular}

\section{Teknik Analisis Data}

Analisis data yang dilakukan dalam penelitian pada prinsipnya adalah menjadikan agar data yang telah dikumpulkan penulis baik secara tertulis maupun lisan dapat bernilai secara ilmiah maupun secara teoritis. Untuk menjawab pertanyaan penelitian ini penulis melakukan analisis data yang didapatkan dengan menggunakan analisis deskriptif kualitatif. Analisis data ini dipilih karna data yang dikumpulkan dari hasil penelitian merupakan data yang berbentuk rangkaian kata-kata dari informan penelitian, bukan data dalam bentuk angka-angka.

\section{HASIL DAN PEMBAHASAN}

\section{Pengelolaan Objek Wisata Lembah Harau}

Pengelolaan Objek Wisata Lembah Harau di Kabupaten Lima Puluh Kota ini melibatkan 10 pemangku kepentingan (stakeholder). Stakeholder tersebut berasal dari instansi pemerintah daerah, pihak swasta, pemangku masyarakat dan masyarakat setempat. Hasil identifikasi stakeholder yang terlibat dalam pengelolaan Wisata Lembah Harau Kabupaten Lima Puluh Kota disajikan pada Tabel berikut. 
Tabel 8. Daftar pemangku kepentingan (stakeholder) yang terlibat dalam pengelolaan Kawasan Wisata Lembah Harau di Kabupaten Lima Puluh Kota

\begin{tabular}{lll}
\hline No & \multicolumn{1}{c}{ Stakeholder } & \multicolumn{1}{c}{ Keterangan } \\
\hline 1 & $\begin{array}{l}\text { Dinas Pariwisata, Pemuda dan Olahraga } \\
\text { Kabupaten Lima Puluh Kota } \\
\text { Badan Perencanaan, Penelitian } \\
\text { pengembangan, Daerah Kabupaten Lima Puluh }\end{array}$ & Pemerintah \\
& $\begin{array}{l}\text { Kota } \\
\text { Balai Konservasi Sumberdaya Alam Propinsi }\end{array}$ & Pemerintah \\
3 & $\begin{array}{l}\text { Sumatera Barat } \\
\text { Dinas Pekerjaan Umum dan Penataan Ruang }\end{array}$ & Pemerintah \\
4 & Kabupaten Lima Puluh Kota & Pemerintah \\
5 & Kecamatan Harau & Pemerintah \\
6 & Nagari Tarantang & $\begin{array}{l}\text { Pemerintah } \\
7\end{array}$ \\
8 & Nagari Harau & Pihak Swasta / Investor Swasta \\
9 & Kelompok Masyarakat (Karang Taruna) & Kelompok Masyarakat \\
10 & Masyarakat & Masyarakat \\
\hline
\end{tabular}

Dari 10 stakeholder yang terlibat tersebut, maka penulis menjabarkan peran masing-masing stakeholder dalam pengelolaan kawasan Lembah Harau :

a. Instansi pemerintah

Dalam mengelola objek wisata Lembah Harau terdapat beberapa instansi yang terlibat dalam pengelolaan objek wisata ini diantaranya : Dinas Pariwisata, Pemuda dan Olahraga, Badan Perencanaan, Penelitian dan Pengembangan Daerah, Dinas Pekerjaan Umum, Kecamatan Harau, Nagari Tarantang, Nagari Harau dan Balai Konservasi Sumber daya Alam Wilayah Sumatera Barat. Masing-masing instansi tersebut terlibat dalam pengelolaan objek wisata Lembah Harau sesuai dengan tugas dan fungsinya masing-masing. Tugas dan fungsinya dapat diuraikan sebagai berikut :

a) Dinas Pariwisata Pemuda dan Olahraga

Dinas Pariwisata Pemuda dan Olahraga merupakan salah satu instansi pemerintah yang lebih banyak terlibat dalam pengelolaan objek wisata. Dinas pariwisata bertugas dalam penyediaan sarana dan prasarana, promosi serta pembinaan terhadap sumberdaya pengelola.

Beradasarkan hasil yang ditemukan dilapangan Dinas pariwisata telah melakukan berbagai upaya untuk mempromosikan objek wisata Lembah Harau dengan melakukan penyebaran leafleat, melaksanakan event-event yang dapat mempromosikan objek wisata seperti pelaksananaan Toer De Singkarak, kegiatan pentas seni seperti Pasa Harau dan lain sebagainya. Selain promosi Dinas Pariwisata juga telah melakukan pembinaan terdapat masyarakat yang terlibat sebagai pengelola melalui pembentukan Kelompok Sadar Wisata (Pokdarwis), pembinaan yang dilakukan berupa peyuluhan tentang bagaimana Penataan Kawasan Objek wisata Lembah yang lebih baik dan meteri tentang Sapta Pesona.

b) Badan Perencanaan, Penelitian, dan Pengembangan Daerah (Bappelitbangda)

Badan Perencanaan, Penelitian, dan Pengembangan Daerah (Bappelitbangda) Kabupaten Lima Puluh Kota merupakan instansi pemerintah yang bidang pekerjaannya terkait dengan perencanaan, lebih tepatnya perencanaan dalam menentukan besaran anggaran dan melihat/ pengkaji seberapa besar potensi objek wisata tersebut dapat dikembangkan dan bagaimana pengaruhnya terhadap pendapatan daerah. Namun dalam pelaksanaan tugasnya mengembangkan objek wisata Lembah Harau, Bappelitbangda tidak terlepas dari Dinas pariwisata.

c) Dinas Pekerjaan Umum dan Penataan Ruang

Dinas Pekerjaan Umum dan Penataan Ruang merupakan salah satu instansi pemerintah dalam pengelolaan dan menjaga Kawasan wisata alam Lembah Harau di Kabupaten Lima Puluh 
Kota yang memiliki berbagai pengaruh dan kepentingannya, terutama dalam bidang infrastrukt dan penataan Ruang. Kegiatan-kegiatan yang dilakukan oleh Dnas PUPR Kabupaten Lima Puluh Kota adalah pengadaan dan Perawatan Jalan, Penetapan wilayah kawasan Wisata Lembah Harau terkait pembangunan, alih fungsi lahan dan status lahan. Kegiatan Dinas PUPR yang telah dilakukan adalah melakukan pelebaran jalan masuk kawasan Lembah Harau, pembukaan dan pengaspalan jalan baru alternatif keluar Kawasan Lembah Harau ke Jorong Ketinggian, Pembangunan Infrastruktur pendukung seperti marka dan penunjuk Jalan di sekitar Kawasan Wisata Lembah Harau, Sedangkan pembinaan terhadap masyarakat adalah melalui program kebersihan lingkungan, pembangunan ifrastruktur melibatkan masyarakat, ikut sertakan masyarakat menjaga infrastruktur kawasan Lembah Harau.

Berdasarkan hasil observasi yang dilakukan penulis untuk jalan menuju kawasan wisata Lembah Harau telah diperbaiki dan diperlebar, namun akses masuk dan keluar hanya terdapat 1 jalur, sehingga masih sering terjadi kemacetan disaat pengunjung ramai. Jalan antar objek wisata juga tergolong kecil atau sempit dan tidak memiliki bahu jalan.

d) Balai Konservasi Sumberdaya Alam (BKSDA) Wilayah Sumatera Barat

Balai Konservasi Sumberdaya Alam (BKSDA) Wilayah Sumatera Barat merupakan instansi pemerintah yang bergerak pada bidang konservasi sumberdaya alam. Berhubung kawasan wisata Lembah Harau merupakan daerah konservasi maka BKSDA harus terlibat dalam pengelolaan objek wisata Lembah Harau, agar kawasan konservasi tetap terjaga. Dalam tugasnya BKSDA bekerjasama dengan Dinas pariwisata memberikan pembinaan kepada masyarakat dan pedagang yang ikut melakukan aktivitas pada objek wisata Lembah Harau tentang pentingnya menjaga kelestarian lingkungan

Berdasarkan observasi yang dilakukan dilapangan bahwa pengawasan yang dilakukan dinas BKSDA masih kurang, hal ini dapat dilihat dari masih banyaknya terjadi perambahan hutan tanpa izin (illegal loging) sehingga ditakutkan akan merusak lingkungan di Kawasan wisata Lembah Harau. Hal ini terjadi karena masih minimnya jumlah tenaga pengawas di kawasan tersebut serta tidak adanya ketegasan yang tertuang dalam aturan pengawasan.

\section{b. Unsur Swasta}

Dalam pengembangan objek wisata Lembah Harau, keberadaan swasta merupakan hal yang tidak dapat dihindarkan. Karena pihak swasta merupakan stakeholder yang berperan sebagai penyedia sarana penunjang, seperti penyedia atraksi, penginapan, hotel dan lain sebagainya. Hal ini sejalan dengan pendapat Wearing dalam Heny (2013) bahwa keterlibatan swasta dalam pembangunan pariwisata berkelanjutan merupakan suatu kewajiban, karena swasta merupakan pihak pelaksana dalam kegiatan pariwisata serta sebagai mitra pemerintah dalam melaksanakan pembangunan pariwisata dibidang pembangunan aksebilitas, dan sebagai pelaksana atau investor

Pemerintah dan pihak swasta harus saling bekerjasama dalam mengembangkan objek wisata. Keterlibatan pihak swasta dalam mengembang objek wisata akan meringankan beban pemerintah dalam hal anggaran, karena pihak swasta akan menyediakan atraksi serta sarana penunjang wisata lainnya yang akan mengundang pengunjung untuk terus datang pada objek wisata dan mereka juga berkewajiban untuk terus meningkatkan daya tariknya agar pengunjung terus berdatangan.

\section{c. Kelompok masyarakat}

Dalam pengelolaan wisata Lembah Harau terdapat beberapa kelompok masyarakat yang terlibat, diantaranya Kelompok Sadar Wisata (Pokdarwis), Karang Taruna, dan Masyarakat Pencita Alam Lembah Harau. Kelompok masyarakat yang terlibat tersebut pada umumnya memiliki peranan dalam menjaga dan melestarikan objek dan daya tarik wisata yang ada serta memberdayakan masyarakat setempat.

\section{d. Masyarakat}

Masyarakat setempat juga memiliki peran dalam mengelola objek wisata Lembah Harau, dimana mereka berperan sebagai penyedia fasilitas penunjang wisata, diantaranya 
warung, tempat parker, pemandu wisata serta homestay. Pada hari-hari tertentu agar menarik pengunjung yang datang masyarakat dilibatkan dalam memberikan hiburan kepada pengunjung. Untuk mengembangkan objek wisata Lembah Harau pemerintah maupun kelompak masyarakat setempat sering memberikan pengarahan tentang sadar wisata, penataan kawasan yang baik, menjaga kebersihan di dalam maupun di sekitar kawasan wisata.

\section{Hubungan Antar Stakeholder}

Menurut Riani (2012) hubungan antara stakeholder dapat dikelompokkan menjadi tiga kelompok yaitu hubungan komunikasi, koordinasi dan kerjasama. Ketiga hubungan tersebut dapat dijelaskan berdasarkan komponen wisata alam yang meliputi konservasi, edukasi, ekonomi dan wisata.

a. Hubungan Komunikasi

Definisi menurut Bungin (2008) menyebutkan bahwa komunikasi adalah sebuah tindakan untuk berbagi informasi, gagasan ataupun pendapat dari setiap partisipan komunikasi yang terlibat di dalamnya guna mencapai kesamaan makna. Dalam komunikasi ada tiga unsur penting yang selalu hadir dalam setiap komunikasi, yaitu sumber informasi, media dan penerima informasi. Stakeholder yang memiliki hubungan komunikasi pada komponen edukasi adalah Disparpora Kabupaten Lima Puluh Kota dengan unsur Masyarakat di Kawsan Wisata Lembah Harau. Stakeholder yang memiliki hubungan komunikasi pada komponen ekonomi adalah Disparpora Kabupaten Lima Puluh Kota dengan Swasta dan Masyarakat. Stakeholder yang memiliki hubungan komunikasi pada komponen wisata adalah Pihak Swasta, Disparpora dengan unsur masyarakat (Wisatawan Lokal Maupun Luar).

a) Hubungan Koordinasi

Hasibuan (2006) menyebutkan bahwa koordinasi adalah suatu usaha yang sinkron dan teratur untuk menyediakan jumlah dan waktu yang tepat dan mengarahkan pelaksanaan untuk menghasilkan suatu tindakan yang seragam dan harmonis pada sasaran yang telah ditentukan. Koordinasi mungkin tidak ada interaksi langsung antara organisasi, tetapi dimana organisasi mempertimbangkan kegiatan pihak yang lain dalam perencanaan yang dimilikinya (Suporahardjo, 2005). Stakeholder yang memiliki hubungan koordinasi pada komponen konservasi dan ekonomi adalah Disparpora Kabupaten Lima Puluh Kota dengan Bappelitbangda Kabupaten Lima Puluh Kota, dan Dinas PUPR. Hubungan antara beberapa instansi pemerintah tersebut terlihat dalam dokumen Tupoksi dan kenyataan di lapangan. Hubungan antara kedua instansi pemerintah tersebut disebut hubungan koordinasi horizontal, dimana hubungan koordinasi horizontal adalah hubungan koordinasi terhadap suatu tindakan atau kegiatan dalam tingkat instansi/organisasi yang setingkat atau sejajar.

Hubungan koordinasi pada Dinas Parpora, Dinas PUPR dan Bapelitbangda dengan Kecamatan Harau sampai kepada tingkat Nagari yang berada di kawasan Wisata Lembah Harau lebih dikatakan vertical Hubungan antara beberapa instansi pemerintah tersebut terlihat dalam dokumen Tupoksi dan kenyataan di lapangan. Hubungan antara instansi pemerintah tersebut disebut hubungan koordinasi vertikal, dimana hubungan koordinasi terhadap suatu tindakan atau kegiatan dalam tingkat instansi/organisasi yang dibawah tingkat atau delegasi.

Hubungan koordinasi pada komponen ekonomi yang terjadi di lapangan antara Disparpora Kabupaten Lima Puluh Kota dengan Bappelitbangda Kabupaten Lima Puluh Kota adalah Bappelitbangda menginventarisasi peluang usaha dan penanaman modal untuk pengembangan pariwisata serta Disparpora Kabupaten Lima Puluh Kota melakukan promosi baik melalui media leaflet maupun di event pameran tingkat kabupaten dan tingkat provinsi sekaligus memasarkan produk wisata. Hubungan koordinasi pada komponen ekonomi yang terjadi di lapangan antara Disparpora Kabupaten Lima Puluh Kota dengan pihak Kecamatan Harau serta Nagari Nagari di Wilayah Kecamatan Harau adalah Disparpora Kabupaten Lima Puluh Kota melakukan promosi baik melalui media leaflet maupun di event pameran tingkat kabupaten dan tingkat provinsi sekaligus memasarkan produk wisata dengan melibatkan langsung pihak 
kecamatan, dan Nagari di wilayah kecamatan Harau untuk ikut serta dan menjadi perpanjangan tangan dari Disparpora.

b) Hubungan Kerjasama

Kerjasama (cooperation) adalah usaha bersama antara individu atau kelompok untuk mencapai satu atau beberapa tujuan bersama (Bungin 2008). Kerjasama dilakukan untuk mencapai misi yang dimiliki mereka dan tujuan yang lebih efektif. Proses terjadinya cooperation apabila di antara individu atau kelompok tertentu menyadari adanya kepentingan dan ancaman yang sama. Kerjasama antar stakeholder Kawasan wisata alam Lembah Harau merupakan hubungan kerjasama atas dasar Tupoksi, aturan kelembagaan, serta kesamaan visi dan misi suatu lembaga, instansi dan kelompok masyarakat. Hubungan kerjasama stakeholder dalam pengelolaan kawasan wisata alam Lembah Harau terletak pada komponen konservasi, edukasi, ekonomi dan wisata. Hubungan kerjasama pada komponen konservasi terjadi antara Disparpora dengan Bappelitbangda, Dinas PUPR dan Balai Konservasi Sumberdaya Alam Wilayah Sumatera Barat dan Kelompok Masyarakat (Karang Taruna, Pokdarwis).

Hubungan kerjasama pada komponen edukasi antara Disparpora dengan Kelompok Masyarakat (Karang Taruna, Pokdarwis). Hubungan kerjasama pada komponen ekonomi terjadi antara Disparpora dengan Pihak Swasta, BKSDA Wilayah Sumatera Barat, Kelompok Masyarakat dan Masyarakat sekitar kawasan Lembah Harau. Hubungan kerjasama dalam komponen wisata terjadi antara Disparpora dengan Pihak Swasta, Kelompok Masyarakat dan masyarakat sekitar kawasan Lembah Harau.

Menurut Siswanto (2005) pengelolaan merupakan suatu aktivitas yang sistematis saling bersusulan agar tercapai tujuan. Pengelolaan kawasan wisata ditujukan untuk melindungi tata nilai asli saat area dikembangkan. Sarana akomodasi, SDM, produk jasa, kepemimpinan, produk dan kemasan, seyogyanya secara hati-hati dikembangkan dengan mengadopsi tata nilai asli serta melibatkan penduduk lokal. Kegiatan pariwisata ini jika dikelola dengan baik akan membawa dampak positif bagi berbagai aspek kehidupan baik pada bidang politik, ekonomi, sosial, budaya, dan lingkungan hidup. Dampak sosial, ekonomi, dan budaya langsung akan dirasakan oleh masyarakat yang memiliki daerah tempat tujuan wisata. Dampak sosial, ekonomi, dan budaya tersebut antara lain adalah: 1) membuka kesempatan kerja dan perluasan lapangan pekerjaan, 2) menumbuhkan aktifitas ekonomi masyarakat, 3) meningkatnya pendapatan perekonomian masyarakat.

Pengelolaan objek wisata Lembah Harau belum mencapai maksimal yang ditandai dengan lemahnya tingkat keterlibatan masyarakat terkait dalam pengambilan keputusan, selain itu keterlibatan pihak ketiga yaitu pihak swasta, dan kebijakan pemerintah daerah dalam prioritas pengelolaan kepariwisataan melalui dukungan alokasi anggaran yang masih minim sehingga belum mampu memaksimalkan pembangunan objek wisata yang ada di Lembah Harau serta ketersediaan infarastruktur sarana dan prasarana yang belum cukup baik. Dengan itu, untuk menciptakan tata kelola yang profesional terhadap pengelolaan objek wisata Lembah Harau pemerintah daerah berperan sebagai fasilisator dalam mewujudkan upaya-upaya ke arah pengembangan pariwisata tersebut melalui kepemimpinan institusinya bertanggungjawab atas empat hal utama yaitu perencanaan daerah atau kawasan pariwisata, pembangunan fasilitas utama dan pendukung pariwisata, pengeluaran kebijakan pariwisata, dan pembuatan dan penegakan peraturan.

Untuk mewujudkan tata kelola yang baik terhadap pengembangan objek wisata diperlukan keseriusan, keterbukaan dan kerjasama yang baik antar pemangku kepentingan (stakeholder) dalam menjalankan tugas dan fungsinya masing-masing. Selain itu kualitas sumber daya pengelolan pariwisata juga sangat berpengaruh terhadap kemajuan dari industri pariwisata tersebut, sebab dalam mengelola/memanajemen pariwisata memerlukan keahlian dan pengalaman, seperti yang dikemukan oleh Salim (1981) "Bahwa berapapun banyak modal yang dimiliki, pembangunan tidak akan terlaksana kecuali disertai dengan sumber daya managerial yang mampu mengelola modal itu untuk pembangunan" 
Berkembangnya suatu kawasan wisata tidak terlepas dari usaha-usaha yang dilakukan melalui kerjasama para stakeholder kepariwisataan, masyarakat dan pemerintah. Munasef (1995) menyatakan bahwa: "pengembangan pariwisata merupakan segala kegiatan dan usaha yang terkordinasi untuk menarik wisatawan, menyediakan semua sarana prasarana, barang dan jasa, fasilitas yang diperlukan guna melayani kebutuhan wisatawan”.

\section{PENUTUP}

Berdasarkan penelitian yang telah dilakukan, dapat disimpulkan sebagai berikut :

1. Manajemen pengelolaan kawasan wisata Lembah Harau selama ini belum dikelola secara optimal, karena pengelola yang terlibat dalam pengembangan kawasan wisata Lembah Harau ini belum menjalankan fungsi-fungsi manajemen dengan baik, dimana untuk mendukung terciptanya pengelolaan kawasan wisata Lembah Harau yang baik sangat dibutuhkan manajemen yang baik untuk mencapai tujuan tersebut.

2. Peran swasta dalam mengelola kawasan wisata Lembah Harau saat ini sangat menonjol, hal ini dapat terlihat dari semakin banyaknya atraksi, wahana, penginapan dan sarana penunjang wisata lainnya yang berkembang di kawasan wisata Lembah Harau, namun hal ini tidak diringi dengan pengawasan yang dilakukan dinas terkait. Sehingga pihak swasta yang berinvestasi di kawasan wisata Lembah Harau tersebut bertindak dengan sendirinya, tanpa memperhatikan lingkungan sekitarnya.

\section{F. DAFTAR PUSTAKA}

Bungin, B, M. 2008. Konstruksi Sosial Media Massa. Jakarta : Prenadamedia Group

Griffin. 2004. Manajemen, alih bahasa Gina Gania. Jakarta: Erlangga.

Hasibuan, Malayu S.P. (2006). Organisasi dan Motivasi - Dasar Peningkatan Produktivitas. Jakarta: Bumi Aksara.

Heny, Urmila Dewi Made. 2013. Pengembangan Desa Wisata Berbasis Partisipasi Masyarakat Lokal Di Desa Wisata Jatiluwih Tabanan, Bali. Jurnal Kawistara Vol. 3 No. 2, 17 Agustus 2013 Hal 117- 226

Mariotti, Yoeti. 1996. Pengantar Ilmu Priwisata, Bandung : Angkasa.

Mary, Parker Follet. 2005. Manajemen. Jakarta: Indeks

Moleong, J. 2012. Metodologi Penelitian Kualitatif. Bandung: PT Remaja Rosdakarya.

Musanef. 1995. Manajemen Usaha Pariwisata di Indonesia. Jakarta : PT Toko Gunung Agung

Natsir, M. 2003. Metode Penelitian. Bandung : Universitas Padjadjaran Bandung

Nugroho, J. Setiadi. 2003. Perilaku Konsumen Konsep dan Implikasi untuk Strategi dan Penelitian Pemasaran. Jakarta: Kencana.

Riani MW. 2012. Mekanisme hubungan para pihak dalam pengelolaan wisata alam di Kota Bandar Lampung dan sekitarnya Provinsi Lampung. [skripsi]. Bogor: Institut Pertanian Bogor.

Salim, Emil. 1981. Pengantar Industrialisasi. Jakarta: UI Press.

Singarimbun, Masri dan Sofian Effendi. 2008. Metode Penelitian Survei. Jakarta: LP3ES.

Siswanto. 2005. Manajemen-Analisa. Yogyakarta : ANDI

Sugiyono. 2009. Metode Penelitian Bisnis. Alfabeta. Bandung

Sunaryo, B. 2013. Kebijakan Pembangunan Destinasi Pariwisata Konsep dan Aplikasinya di Indonsia. Yogyakarta: Gava Media 
Suporahardjo, 2005. Manajemen Kolaborasi. Bogor : Latin

Taylor, Frederick W. 2004. Sistem Administrasi Negara Republik Indonesia. Jakarta: Bumi Aksara Terry, George R.2009. Prinsip-Prinsip Manajemen cetakan 10. Jakarta: PT. Bumi Aksara. 